\title{
The Political Economy of Public Procurement Reform and Democratic Decentralisation in Indonesia
}

\section{Mochamad Mustafa}

\begin{abstract}
Procurement has been one of the most important areas of reform at both national and local levels since the fall of the New Order. This article provides an overview of procurement reform in Indonesia. This paper explains that following the implementation of democratic decentralization in 1999, the Indonesian government has embarked on efforts to ensure that Indonesian procurement procedures comply with international standards, particularly with regards to good governance and the competitiveness of public procurement. However, there is no substantial evidence that the implementation of procurement reform has resulted in more democratic procurement practices. Rather, the process of democratic decentralization has provided a political environment whereby the public procurement budget has become vulnerable to capture by predatory elites for their private interests, a process involving local politicians, local leaders, bureaucrats and business actors. Good governance is hard to expect, unless there is a massive change in the local political structure to limit the predatory elites from capturing local government projects.
\end{abstract}

\section{Keywords}

Political economy; public procurement; good governance;

democratic decentralisation; Indonesia

\section{Introduction}

Public procurement is an important aspect of a country's development. It encompasses the largest portion of public expenditure, covering by one estimate as much as 14\% -20\% of global GRDP (Yulianto and Oeyoen 2011, 8). Public procurement has become the most vulnerable government activity, as it provides multiple chances to both business and public officials to take personal advantage through corrupt and collusive practices. Globally, according to Yulianto and Oeyoen (2011), the World Bank estimates that corruption in procurement increases the market value of public goods and services by $20 \%$, while

Mochamad Mustafa completed his PhD in the Department of Anthropology and Development Studies The University of Adelaide, South Australia.

\section{Corresponding Author:}

Mochamad Mustafa

Email: mochamad.mustafa@asiafoundation.org 
Transparency International projects that corruption in procurement wastes 15\%$29 \%$ of all project costs. In the Indonesian context, government procurement accounts for $40 \%$ of the total national budget. It has been estimated thatIDR 825.8 trillion of the IDR 2,039 trillion state budget is executed through the public procurement process (KPK 2015).

This article discusses the conceptual narrative of public procurement and its importance in good local governance. It also outlines, in chronological order, the development of procurement policies during and since the New Order era, especially the extensive reforms following the fall of the New Order and the implementation of democratic decentralization. The following discussion focuses on narrating the findings from the literature on the current remaining challenges, despite the extensive introduction of change over the last 15 years. Importantly, this paper demonstrates some insights into understanding the politics of public procurement at the local level following democratic decentralization. It argues that democratic decentralization has preserved the old habits of procurement practices including corrupt and collusive patterns of project distribution involving all actors related to public projects. The paper also indicates that the fragmented elite and widening political competition impose increasing financial pressure on local political actors and increase the risk of corruption and manipulation by elite private interests. Consequently, predatory coalitions are dominating the local environment of procurement reform, which potentially affects the effectiveness of reform implementation. In this vein, this paper aligns with a number of scholars' ${ }^{1}$ analysis on democratic decentralization in Indonesia who suggest it has resulted in "elite capture" 2 by those nurtured under the New Order, sustaining the "clientelism" 3 and "patronage system"4 associated with the New Order within the newly empowered local governments.

The discussion in this paper takes place in four sections. First, the author briefly discuss the importance of public procurement reform, as a framework for reading public procurement in the Indonesian context. Second, this section will explain the public procurement policy during the New Order Era, in which procurement businesses relied on political patronage. Third, this section explore procurement reform in the reform era, in this era procurement practices have undergone significant regulatory and institutional reform. In the final section, the author discuss the political economy of public procurement at the local level. In

\footnotetext{
${ }^{1}$ Among others are Robison and Hadiz (2004) and Hadiz (2004; 2010) arguments on the continuation of an oligarchic system to capture democratic institutional reforms.

${ }^{2}$ Defined as the ability of local elites to exploit both formal and informal social and political power to elicit rents and maximise their interests (see Mattingly 2016, 385).

${ }^{3}$ Defined as a 'relationship between individuals with unequal economic and social status ("the boss" and his "clients") that entails the reciprocal exchange of goods and services based on a personal link that is generally perceived in terms of moral obligation' (Briquet 2015, 1).

${ }^{4}$ Defined as a mode of power relations where 'a patron influences the behavior of his clients because he can grant or withdraw benefits, thereby rewarding compliance or punishing disobedience' (Kattering 1986, 4). In political praxis, it also refers to a 'practice in which the political party winning an election rewards its campaign workers and other active supporters by appointment to government posts and by other favours' (Encyclopaedia Britannica 2017).
} 
general, democratic decentralization and the procurement reforms did not lead to good governance at local level.

\section{Literature Review}

\section{The Importance of Public Procurement Reform}

Public procurement is a central pillar for improving good governance in public institutions. It is a process whereby government entities acquire goods and services using public funds from the marketplace (The World Bank 1995). It encompasses processes such as preparing project documents, publicizing project descriptions, inviting bidders, selecting winners, and awarding contracts. Government procurement differs from those in private sector. According to Wittig (in Odhiambo and Kamau 2003, 10):

"Public procurement must be transacted with other considerations in mind, besides the economy. These considerations include accountability, nondiscrimination among potential suppliers and respect for international obligations. For these reasons, public procurement is subjected in all countries to enacted regulations, in order to protect the public interests. It is worth noting that unlike private procurement, public procurement is a business process within a political system and has therefore significant consideration of integrity, accountability, national interest and effectiveness."

Thus, the implications of public procurement implementation depend on how good governance principles are applied. Defective procurement practices will result in high costs for public spending, accompanied by fraud, project delays and increased prevalence of public funds resulting in poor public goods and infrastructure that impact on the quality-of-service delivery.

According to the World Bank (2001), good procurement practices embody principles or values that are universally applied: e.g. maximizing economic growth and efficiency, promoting competition and participation of suppliers and contractors, fair and equitable treatment of all participants, and transparent procedures that eradicate opportunities for corruption and collusive practices (The World Bank 2001, 3). It is important to note that the effectiveness of public procurement is also related to other processes in the government budget cycle, such as budget planning, program planning, project bidding and contracting, project implementation and project delivery (OECD 2006).

Reforms aimed at creating well-functioning procurement mechanisms have become of global concern. Since public procurement contains both economic and political aspects, the trend for global procurement reforms also addresses these two concerns: maximizing value for money and resolving issues about any lack of accountability and transparency, corruption and fraud. In most developed countries, procurement reforms take place within set frameworks to increase value for money through the advancement of effective bidding methods, technology, and strategies (Hunja 2013). They also attempt to meet international obligations such as the World Trade Organization's Agreement on Government 
Procurement or procurement agreements such as the European Union Procurement Directives or the North America Free Trade Agreement (Agaba and Shipman 2007).

In developing countries, however, orientation towards procurement reforms is designed to establish efficient bidding systems to improve accountability, efficiency, competitiveness, openness and transparency. In these countries, improvements usually include the establishment of clear legal frameworks, transparency and law enforcement mechanisms, combined with institutional reform and professional human resources provisions (Agaba and Shipman 2007; Hunja 2013). Hunja $(2013,4)$ states that:

"while many countries have attempted to implement fundamental changes to procurement systems, there isn't much evidence of these efforts achieving fully-fledged, fundamental reforms. Most postcolonial states, for example, have maintained procurement systems that largely resemble pre-independence regimes. Where attempts have been made to bring about significant changes, these have essentially amounted to marginal tinkering with some of the rules while leaving the general framework intact."

Until recently, the ways in which procurement reforms in developing countries have resulted in good governance of government projects and good acquisition have been, and continue to be, difficult to confirm. Hunja (2013) contends that measuring such impacts is difficult to carry out in developing countries. In fact, many of them are still struggling with fundamental changes, such as managing conflicts of interest, establishing sound regulatory frameworks, and dealing with the lack of capacity of public officials.

\section{Methods}

This research draws on both primary and secondary sources of data and utilizes three data collection methods: interviews with key informants (primary data); collection and compilation of statistical data from government sources (primary data); and collection of data from previously published work relate to the theoretical and empirical focus of the article; government, NGO and donor studies and reports and media reports. (secondary data). The analysis is a combination of contextual review of various documents, analytical works and field research using semi-structured interviews.

\section{Results and Discussion}

\section{Public Procurement Policy during the New Order Era}

In the early period of the New Order Era (1965-1998), there were no specific regulations to provide guidelines on how public procurement should be carried out. Guidelines on procurement regulation were integrated into the annual regulations regarding Anggaran Pendapatan dan Belanja Negara - APBN (the national state budget). Hence, the regulations were applied only to the 
implementation of the state budget (KPK 2015). Formal directives on procurement were first introduced in Keputusan Presiden - Keppres (Presidential Decision) No. $11 / 1974$ on the Implementation of the State Budget. This was followed by 11 modifications before the issuance of Keppres No. 17/2000 in $2000 .^{5}$

A significant breakthrough occurred in 1984 with the issuance of Keppres 29/1984 on the implementation of State Revenue and Expenditure, which introduced various measures focused on cost-effective purchasing, bidding, and contract provision procedures (World Bank 2001). The regulation presented four methods for selecting service providers and contractors, which included open bidding, selective bidding, direct appointments, and direct purchasing, all of which were applied according to the size and the characteristics of the projects involved (KPK 2015).

From the above Keppres it is evident that the primary concerns of the procurement regulations were not only transparency and efficacy in public procurement, but also other objectives, such as the promotion of domestic products, and prioritisation of small, local enterprises, especially for small projects (World Bank 2001). The Keppres, for example, put aside the principles of market competition in the case of local economic distribution, by protecting local enterprises. The rule covered the obligation to use local products and services to promote the domestic economy and to give privileges to small businesses for specific projects, to protect weaker groups and local bidders (WB 2001). Since 1994, the updated versions of Keppres No. 29/1984 (Keppres No. 16/1994, Keppres No. 24/1995, Keppres No. 6/1999, Keppres No. 17/2000) incorporated more detailed measurements of transparency principles. These regulations encompassed procedures for pre-qualification, registration and certification of bidders and, importantly, a requirement for wider advertisement of the projects through the media (World Bank 2001, 41).

Nevertheless, in their implementation, these regulatory frameworks appear to have been dysfunctional. The World Bank $(2001,1)$ criticised Indonesian procurement practice in the period as it does not function well. It was not market driven, was prone to misuse and abuse, and reduced value for money for public funds'. Longobserved regulatory issues and procurement implementation deficiencies during the New Order period persisted. The prevailing issues included a multiplicity and overlapping of regulations with a lack of clarity and assurance of transparent mechanisms and competition, the absence of a single authorised procurement policy-making body, poor compliance with the rules and procedures, the lack of an oversight mechanism, lack of public officials' capacity and integrity, and a weak certification system for service providers. Importantly, conflict of interest issues impeded procurement practices, leading to widespread corruption and collusion practices involving the fraudulent behaviour of the public officials and contractors, and uneconomic packaging based on the lobbying processes of interested groups (The World Bank 2001).

5 Keppres No. 17/1974, Keppres No. 7/1975, Keppres No. 14/1976, Keppres No. 12/1977, Keppres No. 14/1979, Keppres No. 14A/1980, Keppres No. 18/1981, Keppres No. 29/1984, Keppres No. 16/1994, Keppres No. 24/1995, and Keppres, No. 6/1999 (KPK 2015). 
The literature suggests that since the New Order, public procurement has been the object of contested interests (Buehler 2012; Hick 2012; van Klinken \& Aspinall 2011; Mietzner 2011; Aspinall 2013b). The patterns of corruption in public procurement followed the logic of broad patterns of power relations in the New Order era, where the collusive networks closed to a narrow circle of patronage alliances within the Suharto regime (Buehler 2012; Aspinall 2013b). Most players from the procurement market came from the main pillars of the Suharto patronage system, which allowed retired military personnel, in particular, to obtain political positions as a reward for their loyalty. Such regime loyalists then had the directive power to decide who had access to partake in government projects. With its centralistic approach, the New Order regime could control public procurement through its tendering body called 'Team 10', which existed at all levels of government. The team consisted of high level bureaucrats and ministries to monitor and control bid implementation at all levels, especially for national budget funded or ear-marked projects, which accounted for most of the relevant government programs (Buehler 2012).

There were also systemic mechanisms, through various regulations, to protect the narrow circle of the New Order alliances for government projects. They included corporatism of business associations ${ }^{6}$ and the setting up of entry barrier measurements to prevent certain groups of businesses from taking part in public procurement processes (Hicks 2012). For example, service providers had to be members of the Indonesian Chamber of Commerce (Kamar Dagang Indonesia KADIN). They also had to subcribe to one of the three sectoral associations: the Indonesian Consultant Association (INKINDO), the Indonesian National Construction Association (Gabungan Pelaksana Konstruksi Nasional Indonesia GAPENSI), and the Association of Supplier Associations (Asosiasi Rekanan Dagang Indonesia - ARDIN). These four associations were notorious as a club for the New Order's business allies, who worked in collaboration with bureaucrats to manage the distribution of available government projects to members of the associations and to distribute kickbacks from this distribution to government officials in return (Hick 2012). In short, in the period of the New Order regime, procurement businesses relied on political patronage rather than their professional expertise to participate in government projects, had to follow the rules of the game provided by oligarchs to serve their centralised system of patronage, and gave privileges to very small groups of Suharto's loyalists and allies.

\section{Procurement Reform in the Reform Era (Era Reformasi)}

Following the fall of the New Order in 1998, procurement practices in Indonesia have undergone significant regulatory and institutional reform. In 2000,

${ }^{6}$ Corporatism, according to Schimitter, 1974 , is 'a system of interest representation in which the constituent units are organized into a limited number of singular, compulsory, noncompetitive, hierarchically ordered and functionally differentiated categories, recognized or licensed (if not created) by the state and granted a deliberate representational monopoly within the respective categories in exchange for observing certain controls on their selection of leaders and articulation of demands and support' (Schimitter, 1974 in Dick and Mulholland 2014, 5). 
the Indonesian government embarked on efforts to transform its procurement frameworks and practices to comply with international standards. The government introduced a regulation that specifically regulates the bidding procedure through Keppres No. 18/2000 on Government Procurement Guidelines, which governs various aspects of the procurement code of conduct, to be implemented by government line departments at national government level and by agencies at local level (KPK 2015). This regulation is specifically designed to achieve the implementation of good governance principles such as accountability, transparency, openness and competitiveness in public procurement (OECD 2007; Buehler 2012).

The Keppres adopted various principles from the previous ordinances, with more thorough clarification of the responsibilities of and the division of labour between project managers and procurement committees, along with the qualifications required. It also introduced ethical guidelines covering the detailed obligations and prohibitions of parties involved in the bidding process (i.e. project managers, procurement oficials and service providers/contractors) (Hick 2012). The Keppres also provided technical guidelines on procurement procedures, including the obligation to conduct project advertisement and open selection processes for more open market competition, in accordance with the World Trade Organisation (WTO) agreement that was ratified in 1974. Specifically for the latter, the regulation abolished the obligation to reserve privileges for certain types of projects for weaker and/or local businesses. However, the Keppres still gave priority to small businesses for small (for projects up to IDR. 1 billion/ US $\$ 130,000$ ) and medium (from above IDR 1 billion/\$130,000 - IDR 10 billion/ US\$1,130,000) projects (The World Bank 2001; KPK 2015). ${ }^{7}$ Importantly, the regulation also abolished the requirement for Indonesian Chamber of Commerce memberships for service providers and delegated the company certification processes from the government to sectoral business associations. The latter encouraged the establishment of various sectoral business associations to implement the business certification function (Hick 2012).

A further improvement occurred with the introduction of Keppres No. 80 /2003. Along with its seven subsequent revisions, updates and modifications, the regulation covered most aspects of public procurement frameworks, including scopes, methods, procurement organisations, and detailed step by step procedures from planning to implementation, including how dispute resolution should be carried out in detail (OECD 2007). The KPK (2014) also notes that the regulation outlined a progressive policy agenda for improving human resources and the institutional streamlining needed for effective bidding processes, such as procurement official certification, and the establishment of particular bodies at national level, whose main function was to ensure the mainstream creation of procurement policies, procedures, standard documents and to oversee compliance by all government agencies and service providers. Another important element of the regulation was the obligation for service providers and contractors to obtain professional and expertise certifications prior to participating in the bidding

${ }^{7}$ Modified to 2016 exchange rate US \$1 = IDR 13,000. 
process. For example, for public works projects, contractors are obliged to obtain certification from business associations, which were established under the supervision of the Construction Service Industry Board (Lembaga Pelayanan Jasa Konstruksi - LPJK). ${ }^{8}$ Early introduction of the use of electronic tendering also appeared in the regulation, even though it was not explained in detail and was an obligatory policy (KPK 2014). Based on the regulation, all projects from IDR 50 million (USD $\$ 5,750$ ) and above had to be procured through an open bidding mechanism, carried out by procurement committees, composed of certified officials (KPK 2015).

In 2005, as part of the implementation of Keppres No. 80, the government established the Center for Public Procurement Policy Reform Taskforces (Pusat Pengembangan Kebijakan Pengadaan Barang/Jasa Publik, PPKPBJP) under the National Planning and Development Bureau (Badan Perencanaan dan Pembangunan Nasional - Bappenas). Its primary tasks were to develop procurement policies, provide technical assistance for procurement related issues, provide training and certification for procurement officials and establish a permanent national body to take over the role of the PPKPBJP for more effective development of procurement policy reforms. In 2006, the PPKPBJP implemented the procurement official accreditation policy, mandating that all bidding processes should be undertaken by certified officials and no others (Sack et al. 2014).

In December 2007, the national government established Lembaga Kebijakan Pengadaan Barang Jasa Pemerintah - LKPP (the National Procurement Policy Agency -NPPA) under the Presidential Decree No. 106/2007 with the primary task of strengthening procurement institutions, formulating national strategic procurement reforms, developing tools to facilitate effective bidding processes and establishing mechanisms to oversee the implementation of public procurement. Following its establishment, the NPPA initiated various programs and policies with the aim of improving procurement practices. It took over the task of the PPKPBJP in providing training, accreditation and technical assistance, and introducing a set of regulatory and institutional reforms.

In 2007, the NPPA established a centralised IT based application called the SPSE - Sistem Pengadaan Secara Electronik (the Electronic Procurement System) to facilitate contractor selection processes through an electronic system. The system aims to simplify procedures, standardize procurement documents, widen service providers' access to government projects, and improve transparency as well as be a monitoring system. The electronic procurement system also changes the nature of government to deal with business interactions for procurement by using the internet for all steps of the procurement process (Yulianto \& Oeyoen 2011; Sack et al. 2014). Prior to 2012, however, the use of SPSE was not compulsory. Despite this,

${ }^{8}$ LPJK is an industry, professional and business association which represents public participation in ensuring the capability of service providers, especially in construction related projects. It was established in 2000, as mandated by Law No. 18/1999 on the construction service. Its main function related to procurement, to accredit business associations and business professions that have the authority to issue professional and expertise certification for service providers and contractors (LPJK 2017). 
the NPPA rolled out the adoption of the system through a massive campaign, training, and facilitating process, to national line ministries and local governments to promote the new mechanism (The Asia Foundation 2012; Sack et al. 2014).

At the same time, the NPPA also launched the framework for the governments' procurement organisation through policies and the introduction of the Unit Layanan Pengadaan - ULP (the Procurement Service Unit - PSU). The basic idea behind the PSU is to centralize the bidding committees across the different units in the government institutions into one organisation for better coordination, control and monitoring. Through the PSU, procurement organisations in the line ministries and local governments become more streamlined. Rather than having scattered ad hoc committees for individual projects in different units (Figure 1) the PSU acts as a taskforce to procure all available projects implemented in different units or agencies (Figure 2). It is expected that the new organisational arrangement will improve public procurement practices in at least three ways. Firstly, it enhances accountability by cutting off the direct relationship between the project manager (the owner of the project) and the bidding participants during the selection process, which was often vulnerable to conflicts of interest. Secondly, it increases the efficient use of certified staff distributions. It mainly deals with the fact that accredited officials used to be in limited supply. Finally, it enables better coordination and monitoring of all projects within different units of line ministries or different agencies of local governments (LKPP 2013).

\section{Figure 1: Conventional procurement committee}

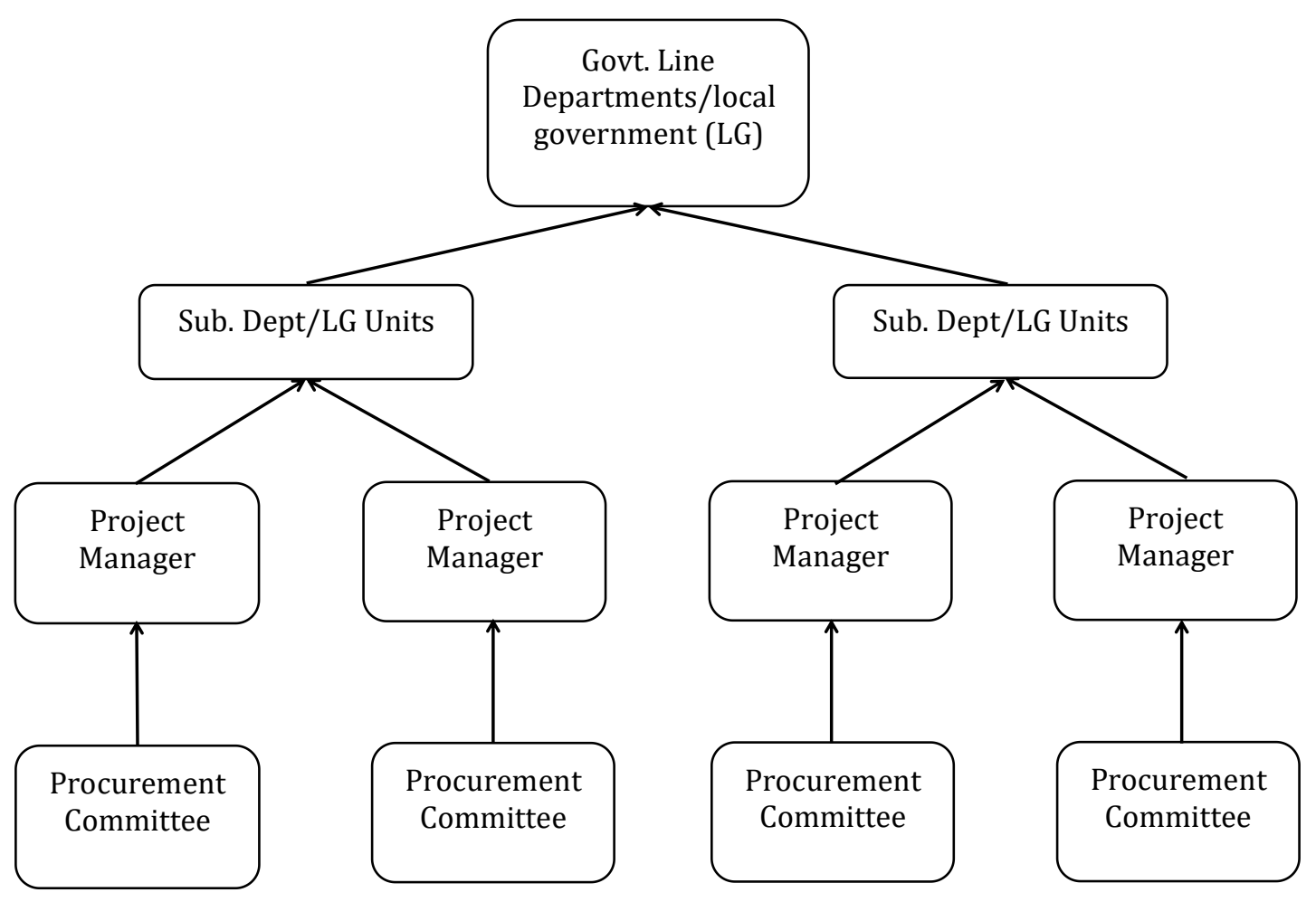


Figure 2: Integrated procurement committee through the PSU

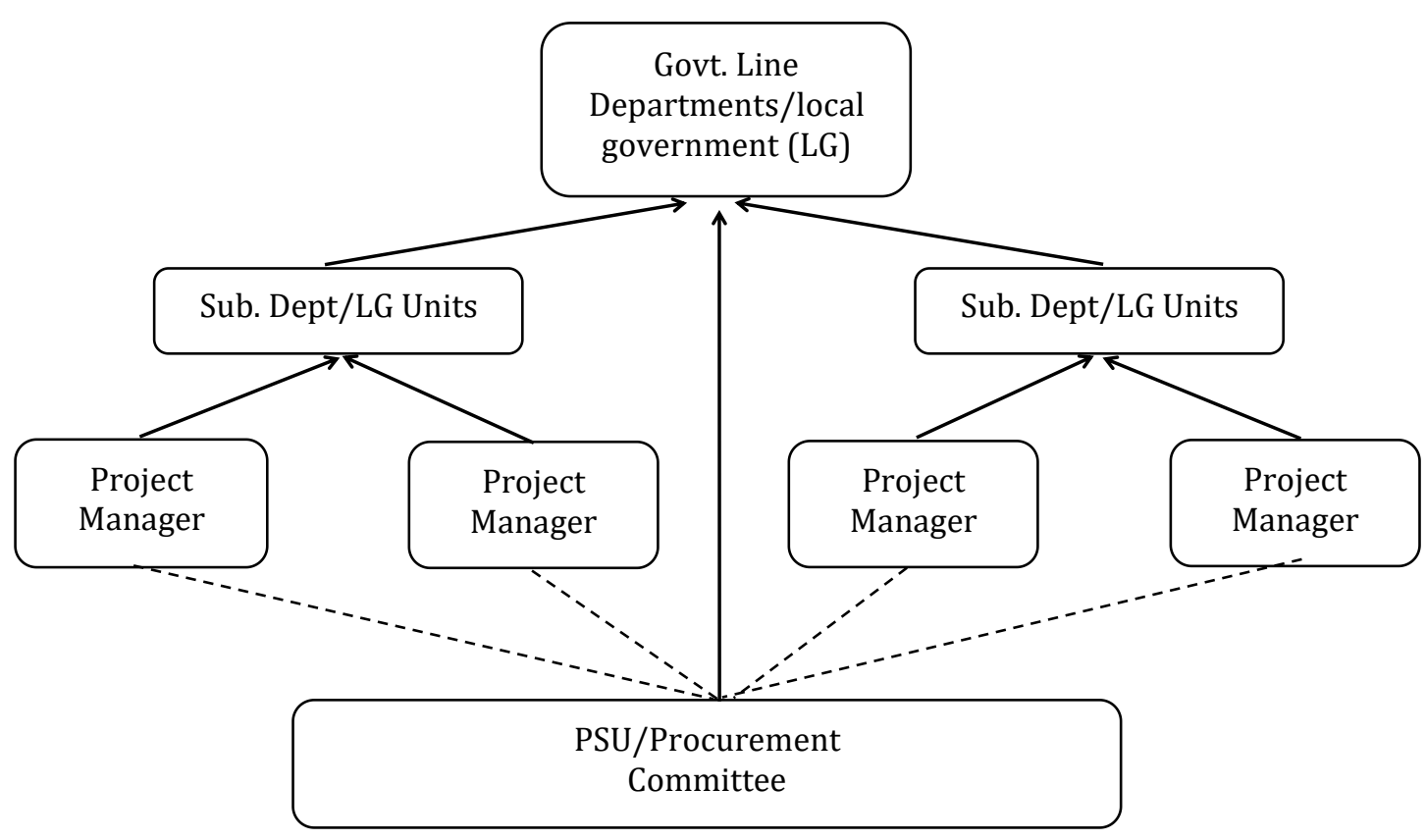

The government further enhanced the legal and institutional frameworks on public procurement through the issuance of Peraturan Presiden - Perpres (Presidential Regulation) No. 54/2010 and its four subsequent revisions and adaptations up to 2015..$^{9}$ The Perpres broadens the scope of public procurement not only to the state but also to include foreign donors and international assistance. The Perpres also restructures the administration of the service providers' selection. The Perpres mandates the enforcement of the implementation of electronic procurement using the nationally established SPSE and the establishment of the PSU. With the new arrangement, the regulation divides the related actors within the government into three main elements which are relatively independent of each other. The first is to provide budget authorities (project owners or project managers) with the task of planning their projects that require a bidding process, to award contracts and monitor contract implementation. The second element is the selection committee, coordinated under the PSU which main functions are to carry out all the processes of individual project bidding up to the selection of the winning bidders. The third element is a project results receiving committee that receives and evaluates the results of the contracted projects (LKPP 2013).

With regards to the e-procurement system, the NPPA also uses eprocurement to integrate all the data into a nationwide electronic monitoring mechanism for the projects implemented through the LPSE. The system also allows

${ }^{9}$ Perpres No. 35/2011, Perpres No. 70/2012, Perpres No. 172/2014, and Perpres No. $4 / 2015$. 
the NPPA to record the profiles of service providers and their procurement activities in the system, including those who are blacklisted, to be able to cross reference their track records (Ikak G Patriasmo, pers. comm., July 8, 2014; Nanang Mairofiq, pers. comm., August 14, 2014). The NPPA has also introduced a national e-catalogue system by providing lists of goods procured by the NPPA for any government institutions to obtain goods through e-purchase without going through the bidding process (i.e. enabling direct purchasing) (Arfani 2016).

The new regulation also simplifies the assortment method. It increases the value limit of direct contracting (sole source) from IDR 50 million (USD \$ 6,250) to IDR 100 million (USD 13,000) and introduces simple bidding processes for any project under IDR 200 million (US\$23,000). ${ }^{10} 13$ The regulation also enforces open bidding for all projects above IDR 200 million (US\$23,000). ${ }^{11}$ The standard remains for consultancy projects above IDR 50 million (USD \$6,250) which need to be undertaken through an open bidding process (Yulianto and Oeyoen 2011). The regulation also allows for the implementation of multi-year contracts and projects (Perpres No. 70/2012), and that the initiation of the procurement process precedes the issuance of National or Local Revenue and Expenditure Budget regulations, with the condition that the project has been agreed in the budgeting and the policy formulation process (Perpres No. 5/ 2015).

Other important aspects of the changes are the strengthening of ethics, transparency and anti-corruption measurements. The regulation clarifies the moral conduct of the officials, abolishes bid security deposits for particular projects, and enforces the publication of the projects' estimated price and the release of all procurement plans in the early days of financial years. The Prepres also requires all actors related to bidding (on both the government's and the provider's sides) to sign integrity pacts as part of the procurement process (Yulianto and Oeyoen 2011; KPK 2015). Advancement also occurs with respect to the complaint handling mechanisms, where the regulation clarifies that all parties have a right to express their written objection to any violation of procedures, inadequate assessment of technical specifications or the misconduct of the procurement authorities after the list of potential winners is publicized. All objections must be reviewed by the PSU, who have an obligation to respond within five days. Such complaint handling is also available through the electronic system as an integral part of the e-procurement menu (Sack et al. 2014).

Beside the above regulatory and institutional frameworks, public procurement reform in the country also reciprocates other regulatory reform frameworks, especially public financial management, and anti-corruption policies. On the public financial management regulations, there are: Law No. 17/2003 on the State Finances, Law No.1/2004 on the State Treasury and Law No. 15/2004 on

${ }^{10}$ Compared with open bidding, simple bidding is conducted within a shorter timeframe, with narrower coverage of publication. The evaluations of technical and financial proposals are implemented simultaneously within a more flexible time frame (Yulianto and Oyen 2011). The process can be implemented outside the e-procurement system and PSU, given the flexibility of the project managers and their committee that forms for the specific purpose of the project to select bidders (Hayie Muhammad, pers. comm., June 25, 2014).

11 The exception applies to emergency responses, military related products and services. 
the State Audit. These rules have transformed the government budgeting process and financial management so that they comply with international standards of modern public financial management, especially financial audit mechanisms (OECD 2007). Public financial management has been enhanced further through these developments, especially with the establishment of the country's supreme audit institution, Badan Pengawas Keuangan (BPK) in 2006. It acts as an external body to review the executive financial management systemsand to report their audit results to the parliament at national, provincial and local levels (Yulianto \& Oeyoen 2011). Since 2001, the government's financial management system is also subject to internal audit from the Badan Pemeriksa Keuangan dan Pembangunan or BPKP (the Internal Financial and Development Audit Bureau), which was established through Presidential Decree No. 103/2001 to carry out regular internal audits of national government institutions. At the provincial and local government levels, such a function is undertaken by the Inspectorate Bureau (OECD 2007).

With regards to the corruption eradication policies, there are anticorruption laws (Law No. 31/1999 and Law No. 20/2001 on Anti-Corruption, and Law no. 28/1999 Clean and Free from Corruption, Collusion and Nepotism of Governance). All those laws clearly regulate matters related to illegal transactions, bribery and embezzlement. The regulations also fortify implementation through the establishment of the Komisi Pemberantasan Korupsi - KPK (the Corruption Eradication Commission) in 2003 through Law No. 30/2002, with special tasks to investigate corruption and collusion practices. Law no. 28/1999 also gives the public the right to seek information and reports of any potential conduct related to corrupt practices and convey their reports to the law enforcement agencies, including the KPK. To reinforce implementation, through Law No. 46/2009 on the Special Court for Corruption Cases, the government also commands the existing courts to establish a specified taskforce to deal with corruption cases (Yulianto and Oeyen 2011).

Importantly, the government issued Law No $14 / 2008$ on public information transparency. It mandates all government entities to disclose government information publically and enforces the establishment of Public Information units at all level of government (Sack et al. 2014). Another regulation which also fosters the transparency of procurement implementation is Law No. 25/2009 on Public Services. The law regulates the interactions between the government and the public and the government's responsibilities in ensuring the implementation of sound governance principles (participation, professionalism, transparency, and accountability) and the achievement of a minimum standard in public service delivery provision (Yulianto \& Oeyen 2011).

From the above-mentioned overview, since 2000, Indonesia's government has been progressing well in its efforts to establish a procurement framework for good public procurement practices, which also emphasizes the need to eradicate corrupt practices. In the view of the Asian Development Bank (ADB) $(2016,1)$, through the various regulatory and institutional reforms, Indonesia has shown 
substantial progress, with the risk of corruption decreasing from 'very high' in 2001 to 'medium' in 2015. The ADB $(2016,2)$ concludes that:

“i) The procurement legal framework has been anchored to the highest law and regulation in the country; (ii) There are national standard bidding documents (SBDs) available in the country, which adopt basic principles of the best international practice. There may be room for improvement, especially for supporting procurement of large contracts that are subject to international competition; (iii) the country's procurement professional certification and training program is in place. Although this program needs to be enhanced, it is able to at least ensure that those staff meeting certain qualifications are involved in procurement decision making and planning; (iv) The transparency of the procurement process is in place. The mandatory use of an eprocurement system and the opportunity for procurement is widely notified in the government's website with free access, and bidders may easily access them for participating; ( $\mathrm{v}$ ) There is a standard procedure for complaint handling and sanctioning system, which is quite effective in reducing the risks of a nonqualified bidder being awarded a contract, or some other irregularities; and (vi) Procurement advisory function and oversight has been practiced by LKPP, and it advocates the compliance of procurement procedures for an audit proceeding."

Some issues, however, remain. Corrupt practices persist in government procurement projects and their implementation, and the capacity of government institutions for managing procurement remains weak. The current operational regulations also scatter in various forms and are issued by different institutions, leading to unclear interpretation, especially with the absence of regulation on the status of the law that supposedly provides a strong guideline and enforcement mechanism for its implementation (ADB 2016).

\section{The Political Economy of Public Procurement at the Local Level}

Democratic decentralisation has resulted in the devolution of substantial power and resources from the central government to 34 provinces and around 508 local districts, which can now exercise greater authority in managing public service deliveries. As a consequence of the decentralization policy, the national government transfers $30 \%$ of its national budget to provinces and districts/cities/municipalities. Under the decentralisation policy, local governments have the authority to manage local public budget spending, including the procurement of goods, services, and public works. From the total amount of the budget, around $40 \%-41 \%$ of the entire local budget is for procured projects (Yulianto \& Oeyoen 2011; Buehler 2012). In 2015, procurement accounted for IDR 405 trillion of the total 1.101 trillion provincial and local government budget (KPK 2015). It is expected that the decentralised public funds will be spent through the available, transparent, competitive, open and accountable processes to ensure maximum value and the greatest level of benefit in terms of local development. The World Bank (2001) claimed in the early stages of decentralization that if managed 
well, decentralization can achieve substantial efficiency gains because decisions will be taken at a level of government that has better information and is more accountable to the public' (The World Bank 2001, 27).

However, despite broad regulatory and institutional reforms, there is a view that democratic decentralization and the procurement reforms did not lead to good governance at local level. Corruption at the local level related to public procurement is still the main issue with implementation of the new systems (Kurniawan 2012; The Asia Foundation 2012; Transparency International Indonesia 2012; KPK 2015; ADB 2016). The Asia Foundation (2012) found that there is no significant evidence of a reduction in the corruption and an expansion in the level of competition or better value for money in districts or municipalities, while the TII estimates that US\$ 4 billion in losses every year were due to corrupt practices in public procurement (Yulianto and Oeyoen 2011). Public procurement accounted for $80 \%$ of the total number of complaints related to corruption in 2011 (Kredibel 2011), and the capacity and integrity of government officials and political interference impeded revitalised procurement practices, leading to widespread corruption and collusion practices (KPK 2015).

The limited capacity of local officials to deal with the complexity of procurement processes and monitor project implementation also contributed to the continuation of the collusive system. Officials often failed to prepare project documents effectively and even asked potential contractors to assist them with distributing kickbacks to parties of interest (B-Trust, 2007). Indonesian Procurement Watch also confirms this to be the situation after conducting a survey of 792 contractors, showing that $92 \%$ of providers have used bribery to win government projects (Indonesia Procurement Watch 2009). Van Klinken and Aspinall (2012) found that in their case study in Aceh, the value of corruption in each project could amount to $20 \%-35 \%$ which is then distributed to various state officials involved at different levels and positions, from planning to project implementation. Project budget mark ups and cutting the product quality have become common practice to recoup the corrupt additional payments (Van Klinken \& Aspinall 2011).

There is also a view that officials and local legislative members often intentionally allocate projects to be implemented by contractors who have a relationship with them (Rahman 2012; Van Klinken \& Aspinall 2011; KPK 2015). According to KPK (2015), in 2015 alone, there were 142 fraud cases related to service provider selection under examination by the KPK, involving politicians, high ranking officials and business actors. The Ministry of Home Affairs in Indonesia reported in 2011 that 17 out of 33 governors and 138 out of 497 regents/mayors were involved in corruption cases, mostly due to abuse of procurement related regulations (Kurniawan 2012). Two informants from the NPPA reveal that, in many cases, despite various regulatory and institutional reforms, the local governments could still manipulate the system to continue collusive and corrupt interests in various ways (Patriasmo, pers. comm.; Mairofiq, pers. comm.). 
There are also indications that, at local level, local governments are reluctant to follow the direction of the reforms, which are designed to strengthen the good governance of public financial management (Patunru \& Erman 2014; the Asia Foundation 2012). The Asia Foundation (2012), for example, found that the introduction of e-procurement did not encourage local governments to maximise the use of the system. According to Sack et al. $(2015,15)$, on average, only IDR 42 billion of local government budgets were electronically tendered in each district that had already implemented e-procurement in 2011 , or only $11 \%$ of the total districts' procurement budgets. There is also a trend to decrease procurement expenditure at a local level in many districts, where $65 \%$ of the regions dropped their procurement budgets from 50\% of total expenditure in 2007 to $41 \%$ in 2011 (Sack et al. 2014, 13).

Evidently the failure of procurement reform to promote good governance at the local level is one of the key problems that impedes the implementation of democratic decentralization, as discussed in the previous chapter, and it highlights the prevalence of elite capture. In the post New Order era, the literature suggests that elite capture has persisted and, indeed, is even more deeply entrenched into society. Van Klinken and Aspinall (2011), Buehler (2012), Dick and Mulholland (2011), and Mietzner (2011) all suggest that linking patronage between politicians and business with bureaucracy continues to breed corruption, negatively affecting government projects. Such a patronage system has even been extended, given the increasing numbers of actors partaking in local politics, their fragmentation and the widening rivalry amongst the elites that that used to be tightly controlled by authoritarian rule (Aspinall 2013b).

There are also suggestions that the fragmentation and heightening of electoral competition has made public procurement prone to elite capture, involving various actors from the elite players, local leaders, politicians, business sectors and bureaucrats at all levels (Van Klinken \& Aspinall 2011; Mietzner 2011; Buehler, 2012). According to Van Klinken \& Aspinall (2011) and Buehler (2012), the introduction of direct elections since 2004 has raised the financial campaign budgets significantly. A local leadership election requires more extensive political resources and campaign finances now, compared with the previous mechanism, which was through local parliamentary voting. Since the local election involves high costs in terms of financial investments, a mayoral/regent candidate needs large financial support from their business channels and political allies to win. In this context, local businesses often act as the campaign's financiers. As a result, campaign financing cultivates a patronage relationship between the contractors and local politicians. The elected politician then seeks to refund their political investment and, importantly to their sponsors, invests in the competition for procurement governance (Mietzner 2011; Van Klinken \& Aspinall 2011; Buehler 2012). Mietzner (2011) indicates that in many cases, the elected officials fall into debt following the election and so their impulse is to capitalise their policy into cash quickly, uncontrollably and regularly.

Parliamentary members have also sought to achieve their predatory interests in government projects. They have often captured government projects 
through their contractor businesses, since many of them have contractor backgrounds (Sack et al. 2014). Aspinall indicates that the local leader in Aceh had to award projects to the contractors preferred by parliamentary members to buy their approval for making regulatory decisions or for support in local head's accountability report meetings (Van Klinken \& Aspinall 2011). Significantly, according to Buehler (2012), for the legislative members, their given budgetary authority enables them to exercise their political power to either negotiate a project's conditions and its budget, or alter the program and budget to meet their own preferences. They also can constrain the public officials within the bureaucracy by blocking the executive budget draft if the draft does not accomodate their interests.

Dick and Mulholland (2011) show that the penetration of elite capture of public procurement is also encouraged by the local budgetary system. The local budget, which tends to be limited and rigidly regulated, limits the ability of local government officials to deal with their day to day issues, especially when it comes to local politics. Such chronic problems have pressured local government to top up their budgets through collecting slush funds to finance the complexity of the state office operations, which are, in many cases, unbudgeted. As a result, manipulating government projects is common practice to recoup the unbudgeted for expenses. Commonly, such informal incomes are almost required to provide the political disbursements known as Dana Taktis (the tactical budget) to manage local politics, especially in the atmosphere of increasing political competition following democratic decentralisation (Dick \& Mulholland 2011).

Significantly, the introduction of democratic decentralisation also increases competition among local bidders. While the policy strengthens the business community's rules for the tendering process, it also results in the flourishing of business associations, leading to increasing fragmentatation of and competition amongst contractors, service providers and their organizations (Hick 2012). There is also a growing number of new businesses which compete for local government projects following democratic decentralisation, but most of them are small entities, with weak capacity, financially, technically and professionally, especially in the contractor business (Larasati \& Watanabe 2009). Within this dynamic, whilst procurement reforms promise opportunities to new players, they also constrain their ability to compete in an established marketplace. Consequently, businesses, especially the contractors, are one of the main groups instigating collusive and predatory behaviours, given their role in local politics and their patronage relationships with local politicians. By participating in government projects, businesses prefer to rely on the rent-seeking mechanism. Potential bidders may have to support local government officials or politicians financially to ensure tender approval, including by becoming the campaign team of any local elections (Mietzner 2011; van Klinken \& Aspinall 2011), however, the contractors undertake these practices so as to avoid competition with those who have better capacity for winning projects in a truly open system (B-Trust, 2007).

Meanwhile, civic society engagement at local level in procurement policy is weak. At national level, there are active NGOs that advocate for procurement 
related reforms, such as the Indonesian Procurement Watch (IPW), Indonesian Corruption Watch (ICW), Transparency International Indonesia (TII), PATTIRO and the Bandung Trust Advisory Groups (B-Trust). They also work at both national and local levels. However, in most districts, civil society involvement in monitoring the public procurement process and implementation is limited, and, if it does exist, lacks the capacity, information and analytical skills to deal with the complexity of procurement issues (Reza Samawi, pers. comm., August 25, 2014; Hayie Muhammad, August 15, 2014; Agung P Permane, August 19, 2014; Mochamad Iqbal, pers. comm., August 25, 2014). The local political environment also contributes to the limited role civil society has to prevail in public procurement issues. Rochman and Achwan (2016) point out that local politics also has an established patronage relationship between the government and civil society, including the local NGOs. The dependency of the local NGOs on the local budget is high and the distribution of assistance funds to NGOs has traditionally been conducted through poor budgeting mechanisms.

In many cases, the NGOs also work to support their politicians, bureaucrats and networks of officials to access financial support (Rochman and Achwan 2016). Interviews with national NGOs working on anti-corruption issues and procurement reform reveal the undemocratic relationships between local NGOs. The idealistic NGO is rare at local level, despite the booming voice of those who claim the importance of the role of NGOs in overcoming corruption and improving good governance. Many NGOs have identified corruption issues and reported them to local prosecutors or through the media. Undeniably, in many cases, these charges been successful and caused many corrupt bureaucrats and officials to be prosecuted due to the corruption laws. However, many NGOs also conducted such activities to increase their bargaining power in accessing local government funds or to source funds from local, serving politicians to intimidate their political opponents (Permane, pers. comm.; Iqbal, pers. comm.; Yuna Farhan, pers. comm., July 02, 2017; Danang Widoyoko, pers. comm., July 02, 2017).

\section{Conclusion}

Following the fall of the New Order's authoritarian government, since 2000 the Indonesian government has embarked on a program to ensure that Indonesian procurement procedures comply with international standards, particularly with regards to accountability, transparency, openness and competitiveness of public procurement. As a consequence of democratic decentralization, local government has full authority to manage the procurement of goods, services and public works. However, rather than resulting in better governance in public procurement, it can be argued that this has actually extended the ability of local elites to capture local government projects. Local government projects have become a market for groups of local elites, involving local politicians, bureaucrats and local contractors. Politically speaking, procurement reform at the local level has been impeded by immense volumes of elite capture, leading to a failure of good governance implementation in procurement practices. Given the political and economic 
dynamics surrounding the implementation of democratic decentralisation and local procurement reforms, good governance is hard to expect, unless there is a massive change in the local political structure to limit the predatory elites from capturing local government projects.[]

\section{Acknowledgements}

This article is adapted from a chapter in my dissertation which submitted for the degree of Doctor of Philosophy in the Department of Anthropology and Development Studies the University of Adelaide, South Australia, 2017.

\section{References}

Agaba, Edgar, and Nigel Shipman. 2007. "Public procurement reform in developing countries: The Ugandan experience". In Advancing public procurement practices, innovation and knowledge sharing, edited by Gustavo Piga and Khi V. Thai, 373-391. Florida: PrAcademics Press.

Arfani, Nurlisa. 2016. "Efisiensi pengadaan barang/jasa dengan e-catalogue”. Jurnal Pengadaan 4, no. 1: 28-50.

Asian Development Bank (ADB). 2016. "Procurement risk assessment"'. Asian Development Bank. Accessed January 15, 2016. https://www.adb.org/sites/default/files/linked-documents/49141-001sd02.pdf.287.

Aspinall, Edward. 2013. "A nation in fragments: Patronage and neoliberalism in contemporary Indonesia." Critical Asian Studies 45, no. 1: 27-54.

B_Trust. 2007. Studi tentang prakarsa reformasi pengadaan barang dan jasa pemerintah, unpublished report.

Briquet, Jean-Louis. 2015. “Clientelism.” Encycloedia Britannica. Aaccessed July 27, 2017. https://www.britannica.com/topic/clientelism.

Buehler, Michael . 2012. "Public procurement reform in Indonesia provinces and districts: The historical institutional context and lessons learned from analytical frame work." Michael Buehler blog. Accessed January 12, 2013. http://michaelbuehler.asia/wpcontent/uploads/2012/11/BuehlerProcureme ntWorldBank120906.pdf.

Dick, Howard, and Jeremy Mulholland. 2016. "The politics of corruption in Indonesia." Georgetown Journal of International Affair 17, no. 1: 43-49.

Encyclopedia Britannica. 2017. "Spoils-system". Accessed July 27, 2017. https://www.britannica.com/topic/spoils-system. 
Hadiz, Vedi R.. 2004. "Decentralization and democracy in Indonesia: A critique of neo-institutionalist perspectives." Development \& Change 35, no. 35: 697-718.

Hadiz, Vedi R.. 2010. Localizing power in post-authoritarian Indonesia: A South Asia perspective. California: Stanford University Press.

Hicks, Jacqueline. 2012. "A false start? Indonesian business associations as democratic actors in the immediate post-Soeharto era." Indonesian Studies Working Papers, no. 15, Department of Indonesian Studies, University of Sydney.

Hunja, Robert. 2003. "Obstacles to public procurement reform in developing countries." In Public procurement: The continuing revolution, edited by Sue Arrowsmith and Martin Trybus, 13-22. The Netherlands: Kluwer Law International Dordretch.

Indonesian Procurement Watch. 2009. Laporan survey jejak suap dalam pengadaan barang/jasa pemerintah. Jakarta: Indonesia Procurement Watch.

Kattering, Sharon . 1986. Patrons, brokers, and clients in Seventeenth-century France. New York: Oxford University press.

Komisi Pemberantasan Korupsi. 2015. Kajian pencegahan korupsi pada pengadaan barang dan jasa pemerintah. Jakarta: Komisi Pemberantasan Korupsi.

Kredibel .2011. "E-procurement: Innovation toward clean procurement". Kredibel vol. 1, 12-13. Accessed August 30, 2013. http://www.lkpp.go.id/v2/files/content/file/MAJALAH_KREDIBEL_EDISI\%20 01-2011.pdf.

Kurniawan, Teguh. 2012. "Regional governance and corruption eradication in Indonesia." the 2011 conference on decentralisation and democratisation in Southeast Asia, 15-17 June 2011, University of Freiburg, Germany, viewed 20 September 2013, http://www.southeastasianstudies.unifreiburg.de/internationalconferences/decentralization-in-southeastasia/conference-guide.pdf.

Larasati, Dewi, and Tsunemi Watanabe. 2009. "Current state of construction industry performance in Indonesia - can it be improved?." JSCE Construction Management 16: 399-410.

Lembaga Kebijakan Pengadaan Barang/Jasa Pemerintah. 2013. Kajian akademis unit layanan pengadaan (ULP). Jakarta: Lembaga Kebijakan Pengadaan Barang/Jasa Pemerintah.

Lembaga Pelayanan Jasa Konstruksi. 2017. “Tentang LPJK”. Accessed June 15, 2017. www.lpjk.org. 
Mattingly, Daniel C.. 2016. "Elite capture: How decentralization and informal institutions weaken property rights in China." World Politics 68, no. 3: 383 412.

Mietzner, Marcus. 2011. "Funding pilkada: Illegal campaign financing in Indonesia's local elections." In State and illegality in Indonesia, edited by Edward Aspinall and Gerry van Klinken, 239-164. Leiden: KITLV press.

Odhiambo, Walter, and Paul Kamau. 2003. "Public procurement: Lessons from Kenya, Tanzania and Uganda." Working Paper, no. 208, Organisation for Economic Co-operation and Development - Development Centre.

Organisation for Economic Co-operation and Development (OECD). 2006. Curbing corruption in public procurement in Asia and the Pacific. Philippines: Asian Development Bank.

Organisation for Economic Co-operation and Development (OECD). 2007. "Snapshot assessment of Indonesia's public procurement system as at June, 2007: Piloting OECD/DAC procurement JV baseline indicator (BLI) benchmarking methodology version 4." OECD. Accessed March 12, 2017. http://www.oecd.org/development/effectiveness/39254688.pdf.

Patunru, Arianto A., and Erman Rahman. 2014. "Local governance and development outcomes." In Regional dynamics in a decentralized Indonesia, edited by Hal Hill, 156 - 185. Singapore: Institute of Southeast Asian Studies.

Rahman, Erman. 2012. "A check on Indonesia's Graft-Ridden procurement games." Asia weekly Insights and Analysis, June 27 2012. Accessed June 15, 2017. http://asiafoundation.org/2012/06/27/a-check-on-indonesias-graftriddenprocurement-games/.

Rochman, Meuthia Ganie, and Rochman Achwan. 2016. “Corruption in Indonesia's emerging democracy.” Journal of Developing Societies 32, no. 2: 259-177.

Robison, Richard, and Vedi R. Hadiz. 2004. Reorganising power in Indonesia: The politics of oligarchy in an age of markets. London: Routledge.

Sacks, Audrey, Erman Rahman, Joel Turkewitz, Michael Buehler, and Imad Saleh. 2014. "The dynamics of centralized procurement reform in a decentralized state: Evidence and lessons from Indonesia." Policy Research Paper, No. 6977, The World Bank.

The Asia Foundation. 2012. Draft report: First batch of case studies of procurement reform at local level. Jakarta: The Asia Foundation.

The World Bank. 1995. Guidelines: Procurement under IBRD loans and IDA credits. Washington, DC: the World Bank. 
The World Bank. 2001. "Indonesia: Country procurement assessment report: Reforming the public procurement assessement system." Report No. 21823IND, The World Bank, Washington DC.

Van Klinken, Gerry, and Edward Aspinall. 2011. "Building relations: corruption, competition and cooperation in the construction industry." In State and illegality in Indonesia, edited by Edward Aspinall and Gerry van Klinken, 239164. Leiden: KITLV press.

Yulianto, Heni, and Jonni Oeyoen. 2011. APEC Procurement transparency standards in Indonesia: A work in progress. Transparency International - USA and Center for International Private Enterprise.

\section{Author Biography}

Mochamad Mustafa completed his PhD in the Department of Anthropology and Development Studies The University of Adelaide, South Australia. His research topic focus on the political economy of bureaucratic reform in Indonesia, more specifically in the area improving public services, local economic policy and procedures, promoting gender responsive and pro-poor local budgets, public procurement reform and increasing transparency and public participation.

Email: mochamad.mustafa@asiafoundation.org 